\title{
RESEARCH ON THE APPLICATION OF MUSIC-BASED PSYCHOLOGICAL ADJUSTMENT IN IMPROVING POSTGRADUATES' MENTAL HEALTH
}

\author{
PESQUISA SOBRE A APLICAÇÃODO AJUSTE PSICOLÓGICO BASEADO NA MÚSICA NA MELHORIADA \\ SAÚDEMENTAL DE PÓS-GRADUADOS
}

INVESTIGACIÓN SOBRE LA APLICACIÓN DEL AJUSTE PSICOLÓGICO MUSICAL EN LA MEJORA DELA SALUD MENTAL DE LOS GRADUADOS

\section{Zhuoran Yin' (iD \\ (Public health Education) \\ 1. School of Music, Nanshan College, Yantai, Yantai, Longkou-265700, China.}

\section{Correspondence:}

Yantai, Longkou-265700, China. w8287566@sina.com.

\begin{abstract}
At present, the mental health problem of postgraduates is still in the highest position, which directly affects the level of intellectual performance in social work. While mastering professional knowledge, it also requires postgraduates to have higher ideological and psychological qualities. On the basis of domestic and foreign research, this study takes the concept and advantages of music-based psychological adjustment as a theoretical basis and, through a large number of questionnaires, combined with the psychological characteristics of science and engineering postgraduates, we use the comparative method, the statistical analysis method and the experimental method to study the influence of musicbased psychological adjustment on the mental health level of science and engineering postgraduates. It further illustrates that music promotes communication between man and nature. Music promotes communication between people and society. Music promotes communication between people and their inner world. Music can also build people's faith and find the home of the soul. It emphasizes the influence of music on postgraduates' emotions. The purpose of this is to build a reasonable and perfect music therapy system, so as to further enrich and strengthen the connotation and effect of mental health education in colleges and universities.
\end{abstract}

Keywords: Music psychological adjustment; Graduate students; Mental health; Application.

\section{RESUMO}

Atualmente, o problema de saúde mental dos pós-graduados continua em sua posição mais elevada, o que afeta directamente o nível de exercício intelectual no trabalho social. Além de dominar o conhecimento profissional, também é necessário que os pós-graduados tenham qualidades ideológicas e psicológicas mais elevadas. Com base em pesquisas internas e externas, este estudo toma o conceito e as vantagens do ajuste psicológico baseado na música como base teórica e, através de diversos questionários, combinados com as características psicológicas dos pós-graduados da área de ciência e engenharia, usamos o método comparativo, o método de análise estatística e o método experimental para estudar a influência do ajuste psicológico com base na música no nível de saúde mental dos pós-graduados em ciências e engenharia. Também ilustramos que a música promove a comunicação entre o homem e a natureza. A música promove a comunicação entre as pessoas e a sociedade. A música promove a comunicação entre as pessoas e seu mundo interior. A música também pode construir a fé das pessoas e encontrar a casa da alma. Este estudo enfatiza a influência da música nas emoções dos pós-graduados. O presente estudo visa construir um sistema de terapia musical razoável e perfeito, de modo a enriquecer e fortalecer ainda mais a conotação e o efeito do sistema educacional em saúde mental em faculdades e universidades.

Descritores: Ajuste psicológico com base na música; estudantes graduados; saúde mental; aplicação.

\section{RESUMEN}

En la actualidad, el problema de salud mental de los posgraduados se encuentra todavía en la posición más alta, esto incide directamente en el nivel de desempeño intelectual en el trabajo social. Además de dominar el conocimiento profesional, también es necesario que los posgraduados tengan cualidades ideológicas y psicológicas superiores. Sobre la base de investigaciones nacionales y extranjeras, este estudio toma como base teórica el concepto y las ventajas del ajuste psicológico basado en la música. Por medio de un gran número de cuestionarios, combinados con las características psicológicas de los posgraduados en ciencias e ingeniería, utilizamos el método comparativo, el método de análisis estadístico y el método experimental para estudiar la influencia del ajuste psicológico basado en la música en la salud mental de los graduados en ciencias e ingeniería. Además, muestra que la música estimula la comunicación entre el hombre y la naturaleza, así como entre las personas y la sociedad y entre las personas y su mundo interior. La música también puede 
fortalecer la fe de las personas y encontrar el hogar del alma. Cabe destacar la influencia de la música en las emociones de los posgraduados. El propósito de esto es construir un sistema de musicoterapia razonable y perfecto, a fin de enriquecer y fortalecer aún más la connotación y el efecto de la educación en salud mental en colegios y universidades.

Descriptores: adaptación psicológica de la música; estudios de posgrado; salud mental; aplicaciones.

\section{INTRODUCTION}

Graduate students are the pillars of the country and society. In order to make graduate students better adapt to the fierce social competition in the future, it is necessary to pay attention to and attach importance to the mental health education of graduate students. ${ }^{1}$ The so-called psychological adjustment ability, in this study, means that junior high school students can actively cope with the pressure through various emotional, behavioral, psychological and other reaction forms in the face of environmental pressure, so that they can better study and live and survive, which is one of the necessary psychological qualities for graduate students. Colleges and universities in China have strengthened the mental health education for postgraduates and postgraduates through various ways and forms, in order to improve their mental health quality. ${ }^{2}$ The introduction of music appreciation course in graduate education curriculum design is not only an important way of national music education, but also an important content of music psychological adjustment for graduate students, which can play a role in reconciling temperament, cultivating sentiment, pleasing body and mind and relieving stress. ${ }^{3}$ A qualified graduate student should not only have excellent ideological character, good professional quality, but also have a healthy psychology. Only in this way can they better adapt to the society, serve the society and play the role of the main force in the construction of the motherland. ${ }^{4}$

In the new period, improving postgraduates' psychological adjustment ability has become one of the important contents of quality education, and its related research has attracted much attention. In daily life and study, most graduate students can set clear goals, get along well with their classmates, and be full of hope and passion for the future. But it is undeniable that some graduate students have certain mental health problems. ${ }^{5}$ At present, music education has been incorporated into the general curriculum system of undergraduates in colleges and universities, but music education for postgraduates is very scarce. ${ }^{6}$ Therefore, through a comprehensive, systematic and in-depth exposition of the concept, function, basic method and application of music psychological adjustment, this paper introduces music psychological adjustment into psychological adjustment and promotes the application of music psychological adjustment in science and engineering graduate students. Music appreciation, a teaching method, can choose appropriate tracks and listening methods according to the characteristics of graduate students, which is most easily accepted by graduate students. Based on the author's practice of music adjustment for postgraduates'mental health, this paper puts forward that it is feasible to use music to adjust postgraduates' mental health in colleges and universities.

\section{Research on music psychological adjustment}

Scientific experimental research has proved that the rhythm pattern and tune system of music have wonderful connection with the physiological rhythm of human body. Different types of concerts make the related parts of the brain control emotions change, and music can even relieve pain. In the aesthetic field of vision, many excellent popular music works have aesthetic value because of their beautiful melody, proper relationship between lyrics and songs, full-bodied singing style, simple and effective development and unique popular expression concept. As a kind of art field, the particularity of music itself in composition materials, presentation methods, emotional factors, etc. is the main manifestation that music can be distinguished from other art forms. Emotional life goes deep into our bodies, so that we often don't know what kind of feeling our bodies are in. ${ }^{7}$ Therefore, through proper and effective mental health education, graduate students should be led out of the bad shadow and misunderstanding of psychological anxiety, and gradually improve their correct cognition and attitude towards society. Music therapists use music's great influence on emotions to change people's emotions and finally change people's cognition.

The scores of 30 subjects' pre-test Emotional-Social Loneliness Questionnaire, Accommodation Scale, Social Avoidance and Distress Scale were not significantly different, but comparable. After the intervention of impromptu music therapy, the scores of Accommodation Scale, Social Avoidance and Distress Scale showed significant differences between the experimental group and the control group. In the stage of activity import, firstly, music depicting nature is used, with the theme of eliminating fatigue, close to the real life scene and experience of graduate students, and smoothly import music aesthetic activities; Keep a comfortable state, and then concentrate on imagining some comfortable and relaxed scenes as realistically as possible. The third is muscle relaxation. Muscle relaxation is a kind of deep relaxation. The comparison results between the experimental group and the control group for accommodating others are shown in Table 1 below.

It can be seen from Table 1 that the scores of the experimental group increased by $8.31 \%$, while those of the control group increased

Table 1. Comparison of accommodating others between song discussion experimental group and control group.

\begin{tabular}{|c|c|c|c|c|c|c|c|c|c|}
\hline Group & Measuring time & The number of & Average & $\begin{array}{l}\text { Standard } \\
\text { deviation }\end{array}$ & $\begin{array}{c}\text { Difference } \\
\text { between pre-test } \\
\text { and post-test }\end{array}$ & Bonus rate & $\begin{array}{c}\text { Difference } \\
\text { between groups }\end{array}$ & $\mathrm{T}$ & $\mathbf{P}$ \\
\hline \multirow{2}{*}{$\begin{array}{l}\text { Experimental } \\
\text { group }\end{array}$} & Pre-test & \multirow{2}{*}{15} & 60.31 & 5.01 & & & & & \\
\hline & Post test & & 62.12 & 4.28 & 6.33 & $8.31 \%$ & & & \\
\hline \multirow{2}{*}{ Control group } & Pre-test & \multirow{2}{*}{15} & 59.47 & 8.96 & & & & & \\
\hline & Post test & & 60.73 & 1.11 & 0.71 & $0.33 \%$ & & & \\
\hline $\begin{array}{l}\text { Difference } \\
\text { comparison }\end{array}$ & & & & & & & 4.36 & 1.271 & $0.47^{*}$ \\
\hline
\end{tabular}


by $0.33 \%$. Furthermore, the difference between the two groups before and after the test is tested by T-test. The above results show that the group intervention of group reception music therapy, that is, song discussion, has a significant difference in the change of accepting others between the two groups.

The psychological process of music aesthetic appreciation and the division and description of the stages of aesthetic psychological process are the basis of music aesthetic appreciation and the basis of constructing music aesthetic activities. The result of the whole performance process may be harmonious and pleasant to hear, or it may be disorganized, which reflects the relationship state of group members. In this state, music psychological education plays a role in psychological problems, and is gradually recognized by some highly effective people. And implement this method, and play a better role in psychological education; Too strong negative stimulation is closely related to the situation at that time. As long as you are good at breaking away from the unfavorable situation, it becomes relatively easy to control emotions. Therapists can point out their empathy reaction directly to the helper. This means that when the help seeker is aware of this empathy reaction, he can directly point it out and let the help seeker perceive it himself. Comparison of social avoidance and distress between experimental group and control group is shown in Table 2.

It can be seen from Table 2 that the scores of the experimental group decreased by $33.74 \%$, while those of the control group increased by $59.16 \%$. The scores of social avoidance and distress of the control group and the experimental group changed inversely. Furthermore, the differences between the two groups before and after the test are tested by T-test. The above results show that the group intervention song discussion of group reception music therapy has caused significant differences in social avoidance and distress changes between the two groups.

A self-made questionnaire on music preferences of postgraduates was used to investigate the types and degrees of music that postgraduates like. The questionnaire includes 10 aspects and 2 open questions. This paper mainly investigates the music literacy of postgraduates. It specifically involves gender, grade, major, favorite degree, type, and feelings about music. Two open questions, "What do you want for music?" and "What do you think the long-term listening to music will affect a person's mood?", are carried out to find out the purpose and emotional changes of postgraduates"listening to music", and the music types are refined by combining the items in the questionnaire. The results show that (see Table 3).

It can be seen from the analysis table of the time for postgraduates to enjoy music every time that postgraduates like music and enjoy it for a long time. The time for enjoying music every time is concentrated from 1 hour to 3 hours and more than 3 hours, and the experimental group enjoys music more than 3 hours at a time. The control group focused on 1 hour to 3 hours. Among them, there are many "listening frequently" selectors mentioned in the questionnaire. Therefore, almost all graduate students like to enjoy music, and each time it takes a long time.

Therefore, they have a potential and profound impact on the progress of psychotherapy. Music can not only be appreciated by people, but also guide people's psychology. What is important is that music is easily accepted by graduate students. Because of its diversity, music has become a part of many graduate students'lives in real learning. The SCL-90 scale was used to test the experimental group before and after the implementation of music group therapy, and the results are shown in the following Table 4 (Mao Xiaorui 2018):

Table 4 shows that there is a significant difference in the total mean score before and after the test in the experimental group $(P<0.01)$, and all the seven factors have improved to varying degrees, among which there are significant differences in the two factors of compulsion and interpersonal relationship $(P<0.01)$, and significant differences in the three factors of interpersonal sensitivity, anxiety and terror $(P<0.05)$. This shows that music group psychotherapy can significantly improve and promote the overall mental health of graduate students.

\section{CONCLUSIONS}

Music education has a positive impact on postgraduates' mental health. Colleges and universities should fully realize the important role of music education in mental health education and increase the coverage and influence of music education. The analysis shows that the autistic and introverted postgraduates of science and engineering are often unwilling to accept psychological adjustment methods such as talking and lectures, and the effect often fails to reach the effective expected value. Taking music therapy is an important means of psychological education for

Table 3. Analysis of the time for postgraduates to enjoy music every time.

\begin{tabular}{c|c|c|c|c|c|c|c|c}
\hline \multirow{2}{*}{ Group } & \multicolumn{2}{|c|}{$\begin{array}{c}\text { Time for one } \\
\text { or two songs }\end{array}$} & \multicolumn{2}{c|}{$\begin{array}{c}\text { Less than } \\
\mathbf{1} \text { hour }\end{array}$} & \multicolumn{2}{c|}{$\begin{array}{c}\mathbf{1} \text { hour to } \\
\mathbf{3} \text { hours }\end{array}$} & \multicolumn{2}{c}{ Over 3 hours } \\
\cline { 2 - 9 } & $\mathbf{N}$ & $\%$ & $\mathbf{N}$ & $\mathbf{\%}$ & $\mathbf{N}$ & $\%$ & $\mathbf{N}$ & $\%$ \\
\hline $\begin{array}{c}\text { Experimental } \\
\text { group }\end{array}$ & 7 & 28 & 6 & 27 & 8 & 32 & 9 & 37 \\
\hline Control group & 3 & 14 & 3 & 14 & 12 & 45 & 5 & 17 \\
\hline
\end{tabular}

Table 4. Test results of the overall level of mental health in the experimental. group.

\begin{tabular}{c|c|c|c|c|c|c}
\hline \multirow{2}{*}{ Factor } & \multicolumn{2}{|c|}{ Pre-test } & \multicolumn{2}{c|}{ Post test } & \multirow{2}{*}{ T } & \multirow{2}{*}{ P } \\
\cline { 2 - 5 } & $\mathbf{M}$ & $\mathbf{S D}$ & $\mathbf{M}$ & $\mathbf{S D}$ & & \\
\hline Total mean score & 1.362 & 0.334 & 1.622 & 0.339 & 4.263 & 0.03 \\
\hline Force & 2.014 & 0.314 & 1.323 & 1.262 & 1.223 & $0.372^{* *}$ \\
\hline $\begin{array}{c}\text { Interpersonal } \\
\text { relationships }\end{array}$ & 1.846 & 0.815 & 1.982 & 0.821 & 3.401 & $0.041^{*}$ \\
\hline Depression & 1.891 & 0.482 & 1.762 & 0.561 & 2.852 & 0.372 \\
\hline Anxiety & 1.643 & 0.520 & 1.508 & 0.442 & 4.127 & $0.002^{* *}$ \\
\hline Terror & 1.773 & 0.638 & 1.663 & 0.483 & 2.031 & 0.076 \\
\hline Paranoid & 1.801 & 0.416 & 1.302 & 0.431 & 3.792 & $0.130^{*}$ \\
\hline Other & 1.865 & 0.372 & 1.437 & 0.372 & 1.243 & $0.722^{*}$ \\
\hline
\end{tabular}

(Note:* * means $\mathrm{P}<0.0 \mathrm{l},{ }^{*}$ means $\mathrm{P}<0.05$ )

Table 2. Comparison of social avoidance and distress between song discussion experimental group and control group.

\begin{tabular}{|c|c|c|c|c|c|c|c|c|c|}
\hline Group & Measuring time & The number of & Average & $\begin{array}{l}\text { Standard } \\
\text { deviation }\end{array}$ & $\begin{array}{c}\text { Difference } \\
\text { between pre-test } \\
\text { and post-test }\end{array}$ & Bonus rate & $\begin{array}{c}\text { Difference } \\
\text { between groups }\end{array}$ & $T$ & $\mathbf{P}$ \\
\hline \multirow{2}{*}{$\begin{array}{l}\text { Experimental } \\
\text { group }\end{array}$} & Pre-test & \multirow{2}{*}{15} & 7.36 & 5.37 & & & & & \\
\hline & Post test & & 4.24 & 3.71 & -2.72 & $-33.74 \%$ & & & \\
\hline \multirow{2}{*}{ Control group } & Pre-test & \multirow{2}{*}{15} & 8.01 & 5.51 & & & & & \\
\hline & Post test & & 10.61 & 6.91 & 4.01 & $59.16 \%$ & & & \\
\hline $\begin{array}{l}\text { Difference } \\
\text { comparison }\end{array}$ & & & & & & & 9.01 & 1.753 & $0.41^{*}$ \\
\hline
\end{tabular}


postgraduates, it constantly regulates mental health problems, prevents psychological diseases of postgraduates, and improves psychological interest. Therefore, constructing a music therapy system in the postgraduate mental health education is an important supplement to the existing postgraduate mental health education, which can greatly enrich and strengthen the postgraduate mental health education. According to the situation of graduate students and the content of their works, we should choose appropriate ways to enjoy them, so that music can really provide beautiful feelings, purify the soul and cultivate sentiment.

The author declare no potential conflict of interest related to this article

AUTHORS' CONTRIBUTIONS: The author has completed the writing of the article or the critical review of its knowledge content. This paper can be used as the final draft of the manuscript. Every author has made an important contribution to this manuscript. Zhuoran Yin's Orc card number is 0000-0002-0893-863x; zhuoran Yin: writing and execution.

\section{REFERENCES}

1. Qihui J. Research on the effect of psychological adjustment of music on the mental health of college students. Northern Music. 2017; 037(023):220-222.

2. Yuzhi H. Using music appreciation as a medium to open the window of college students' minds-Music appreciation and the adjustment of college students' mental health. Journal of Liaoning Medical College (Social Science Edition). 2015; 000(002):120-122 .

3. Yong C. Mental health and psychological adjustment of civil servants. Journal of Liaoning Administration College. 2015; 000(011):67-71.

4. Handschin C, Spiegelman BM. The role of exercise and PGC1 1 alpha in inflammation and chronic disease.
Nature. 2008; 454(7203):463-9.

5. Guifen H. A preliminary study of the application of music in psychological health education courses for college students. Journal of Jinan Vocational College. 2019; 000(001):81-83.

6. Weilong C, Tiangang C. A Study on the Effect of Music Education on the Mental Health of Higher Vocational Students. The Times of Think Tanks. 2017; 10(05):198-200.

7. Lee IM, Shiroma EJ, Lobelo F, Puska P, Blair SN, Katzmarzyk PT, et al. Effect of physical inactivity on major non-communicable diseases worldwide: an analysis of burden of disease and life expectancy. Lancet. 2012; 380(9838):219-29. 